\title{
Innovation of Art Teaching Mode in Colleges and Universities under the Context of Education
}

\author{
Xiaolong Wang, Ling Cai \\ School of Fine Arts, University of Jinan, Jinan 250022, China \\ soa_wangxl@ujn.edu.cn
}

Keywords: college art; teaching mode; studio teaching

\begin{abstract}
In order to improve the current traditional art teaching mode in colleges and universities and cultivate the innovative thinking of art students, on the basis of studying the traditional art teaching mode and the current situation, the teaching mode of art major in colleges and universities is innovated and the studio teaching mode is introduced, which is a kind of "school-enterprise cooperation and work-study combination" mode. Firstly, the current situation of traditional teaching mode in several art colleges is introduced, then the advantages of studio teaching mode in talent cultivation are drawn out. Subsequently, the teaching mode of art major in a university in Zhejiang Province is analysed through a practical case, and then the conclusion of this study is drawn that this studio teaching mode has advantages for students and universities.
\end{abstract}

\section{Introduction}

In the context of contemporary education, the teaching of artistic painting creation in colleges and universities is an important part of the construction of the discipline system of Chinese painting and a demonstration of its achievements, and the contents involved are also the results of many aspects. As a result, the pre-construction is indispensable. The training objectives of relevant talents, the curriculum and the teaching ideas and methods of teachers in schools have great influence on students' creativity. Enhancing the professional knowledge and skills of arts is to solve the problem of generality, while improving students' artistic innovation ability is to solve the problem of individuality. Only the individuality constructed based on generality and conforming to the law of generality can become a real individuality with a certain depth and height and a real artistic innovation.

At present, many art education majors in teachers' colleges are still the traditional class teaching mode with teachers as the main part. When teaching art theory, teachers infuse students with the content already determined in the textbooks in the form of "one speech ". Students do not need to consider but accept all. This is very disadvantageous for students' independent innovation ability and talents training. Therefore, the studio teaching mode is introduced to carry out research. Teaching through this "school-enterprise cooperation and work-study combination" mode is conducive to the cultivation of talents in colleges and universities, as well as the promotion of educational resources.

\section{State of the art}

The advancement of basic education curriculum reform has put forward higher requirements for arts in colleges and universities. At that time, the status of art teachers in primary and secondary schools in humanistic literacy, educational concepts, teaching methods and other aspects cannot meet the needs of basic education curriculum reform [1]. The rigid and single teaching mode and repetitive reproducible depiction of objects will make it difficult to form a close and coherent connection between the daily basic training and the creation of works. The art specialty course of art education specialty in normal universities should run through the cultivation of the creative ability of artistic individuality from the teaching objectives and teaching modes [2]. Art 
examination-oriented education is a distorted and alienated art education. It occurs in professionaloriented art education, which is a narrow and utilitarian tool education mode that regards the college entrance examination for art major as the sole purpose of education [3,4]. Studio teaching is a new teaching mode which integrates teaching and practice in the traditional classroom environment. Under the guidance of the instructor, it is necessary to introduce relevant social practice projects or teaching cases to create or simulate the environment of social work posts for students, combine classroom teaching with social practice, narrow the gap between school teaching and social vocational job demand, and improve students' employment competitiveness [5]. Studio teaching is an important bridge extending from classroom teaching to social practice [6].

\section{Methodology}

\subsection{Traditional art education mode}

The art training mode of pre-college entrance examination under the dual background of examination-oriented education and college enrolment expansion. Under the circumstances of examination-oriented education mechanism, the college entrance examination for art majors naturally cannot escape the shadow of examination-oriented education which only pursues the rate of entrance. Art examination-oriented education is a distorted and alienated art education that occurs in professional-oriented art education. It is a narrow and utilitarian tool education mode that regards art major college entrance examination as the sole educational purpose. Art examinationoriented education upholds all the characteristics of general examination-oriented education, turning creative and individualized art learning into a kind of knowledge-based and mechanical learning. In recent years, there has been a boom in the art training industry before the college entrance examination. In order to pass the examination for art majors, students have participated in a shortterm pre-examination art training institution which lasts for one year, one season and even more than half a year. The original individualized and innovative art education has been transformed into a stylized and repetitive training mode in order to achieve the goal of achieving good results in art examination through this mechanical training mode. Moreover, repetitive examination contents and silent writing test methods are also conducive to the existence of this training mode. The subjects of the National Fine Arts College Entrance Examination are almost sketches and powdered water or sketch. The content of the examination is mostly still life or figure portraits such as fruits, linings, glassware. Although the form of the examination is divided into two kinds of sketching and silent writing, the recruits are required to write dictation in order to operate more simply. Under such circumstances, the students majoring in fine arts education in normal universities, on the one hand, have relatively low overall cultural quality compared with the students majoring in culture; on the other hand, their professional abilities are poor, and the theory of fine arts such as history of fine arts and introduction to fine arts almost starts from zero, and their knowledge structure is weak. Without theoretical knowledge as the basis and support, it is only for the stylized and repetitive training of skills, and is limited to the mechanical training of powder and sketch, which seriously damages students' artistic individuality and innovation ability.

Class teaching mode. Modern teaching emphasizes students as the subject and teachers as the leading role. There should be frequent interaction between teachers and students and between students in the process of teaching. However, the traditional class teaching mode is obviously difficult to achieve these. This kind of teaching mode has certain effect on teaching the most basic knowledge and skills, but it is difficult to achieve ideal effect on the professional theory knowledge and skills principle that require students to think for themselves at a slightly deeper level. Moreover, once this teaching mode is carried on for a long time, it will inevitably make students' art knowledge and skill structure biased and solidified so that it is weak. It is also easy to develop dependence in learning, so that it is accustomed to accept conclusive and deterministic knowledge, lacking independence and autonomy, and difficult to develop self-exploration, self-speculation and self-innovation consciousness and ability. 


\subsection{Talent training based on studio teaching mode}

The establishment of studio-based teaching mode has provided art teaching in colleges and universities with a talent training mode that meets the needs of the market. According to the analysis of the teaching mode of work-study combination under studio-based system in higher vocational colleges all over the country, there are three typical teaching modes at present.

"Workshop" teaching mode. This teaching mode expands classroom teaching, introduces highquality social resources into classroom, builds a teaching platform for cooperation between schools and enterprises, supplements practical and applied teaching cases, and makes teaching more comprehensive. And it also standardizes the management system of enterprises, well guides students to employment, also build an entrepreneurship platform for students.

"Order-based" teaching mode. Order-based training is also called talent customization. It is the cooperation of schools and enterprises to train professional and technical personnel according to the specific requirements of enterprises and job requirements. Implementing order-based training is another way for art design majors in Higher Vocational Colleges to cooperate with schools, enterprises and institutions to achieve mutual benefit and win-win situation. From this, it can be seen that order-based training is another teaching reform mode that should be advocated in Higher Vocational education. At present, various Higher Vocational Colleges in China are actively responding to the call of the Ministry of Education, constantly mining social resources, cooperating with industry superior enterprises, and vigorously carrying out the teaching reform of this mode.

Studio project teaching mode. Studio project teaching mode refers to the teaching activities conducted by the relevant instructors and project managers in the studio, which are guided by the completion of the project on the basis of the close cooperation between the college and the social superior enterprises and the direct introduction of the design project, design and development project or production task of the enterprise into the school practice studio. Students makes driven learning by the completion of projects. Project-based teaching mode is a common teaching reform mode adopted by various Higher Vocational Colleges in China, and it also meets the requirements of the Ministry of Education to promote Higher Vocational education teaching reform and innovation.

\subsection{Studio teaching mode reform}

Personnel division. Establishing studio system: on the one hand, it is the need of discipline and professional development; on the other hand, it is the need of professional personnel training. The specific division is as follows:

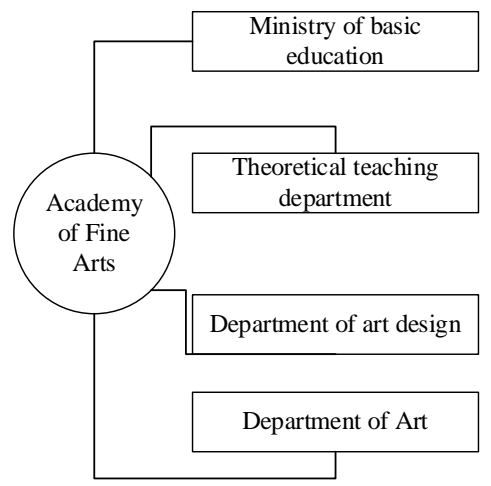

Figure.1 Division of studio settings

Handover of studio teaching: 

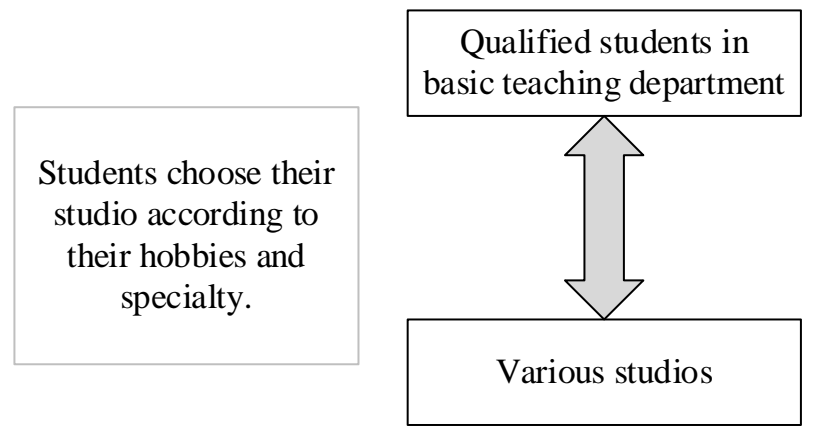

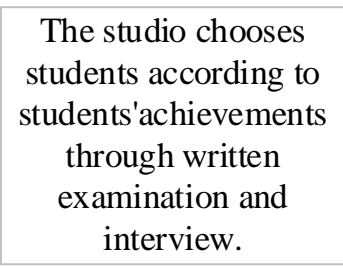

The studio chooses students according to students'achievements through written interview.

Figure.2 Handover between basic teaching department and studio

In addition, studios can be chosen. Students with outstanding grades are encouraged to take more than one studio courses.

Curriculum setting:

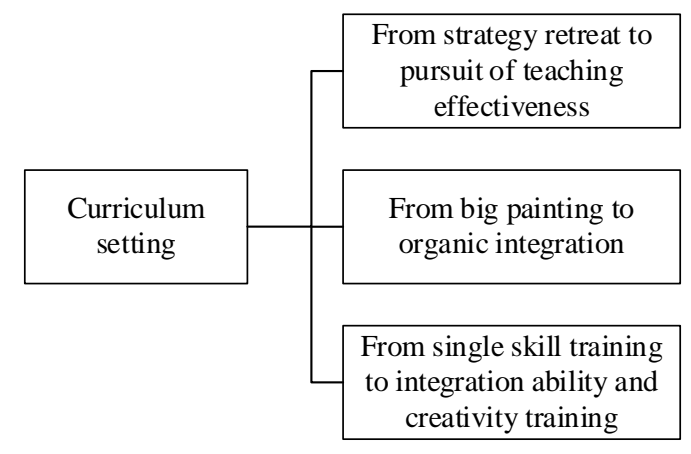

Figure.3 Curriculum optimization setting

Teaching innovation:

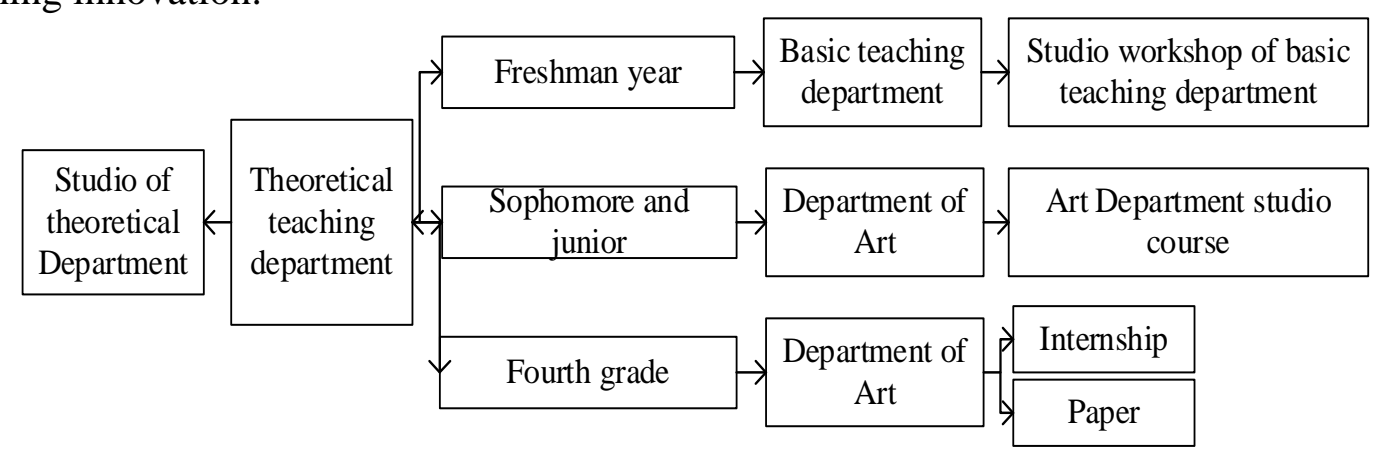

Figure.4 Teaching flow of art department studio

The whole school system of arts department adopts three-stage teaching mode, as follows:

In the first grade, under the arrangement of the studios of the basic ministry, basic teaching is carried out, and the basic skills of painting are educated and assessed to lay the foundation for entering the studio. Studio basic teaching emphasizes the understanding and experience of artistic rules and individual language of painting, fully grasps the dialectical relationship of gradual and progressive basic training, and pays attention to the integrity and coherence of basic courses.

In the second and third grades, enter the training of professional skills, methods and techniques in various professional studios, focus on solving the problem of artistic expression and emphasize the cultivation of creative thinking as the core of teaching thought. On the basis of emphasizing the feelings of life and spiritual experience, it is necessary to make comprehensive and innovative artistic creation.

In the fourth grade, it is required to implement practice teaching, project practice and creative practice as well as thesis writing, and contact the educational practice school for practice.

In the whole school system, the theoretical teaching department carries out theoretical teaching throughout, including classroom teaching, academic lectures, academic activities, etc. It grasps academic ideas and teaching characteristics, observes and ponders on relevant issues of art 
experiment and teaching practice from a theoretical perspective, and cultivates students' analytical ability, research ability and innovation ability through practice and theoretical learning.

In addition, according to the nature of teaching content in different periods, it can be roughly divided into three stages:

Stage where technology and foundation are the subject: First grade students learn basic modelling technology in semi-open classroom, and get relevant credits.

Stage where art and specialty are the subject: Second grade students choose to enter various professional studios, and according to the teaching plan formulated by the studio, learn the skills of artistic expression for two years. The second and third two grades have closed classroom learning in the same studio in different periods.

Stage where academic and practice are the subject: Grade 4 enters an open classroom to create, design and research under the guidance of a studio tutor, and to conduct research-based learning.

\section{Results and discussion}

\subsection{Conducive to the development of students' ability in many aspects}

Studio-based teaching mode is not only a simple form of teaching-oriented organization. It is not only conducive to the improvement of students' professional ability, but also has the characteristics of life and collectivization. Free and warm learning environment and learning methods are conducive to students' happiness, healthy psychological state and positive outlook on life and the world. Moreover, it is also conducive to the cultivation of students' self-confidence, self-learning ability, communication and expression ability, organizational and coordination ability and other intellectual and non-intellectual factors.

\subsection{Helpful for the construction of school teacher powers and the rational utilization of teaching resources}

Studio-based teaching mode has relatively higher requirements for teachers, so the implementation of studio-based teaching mode will promote the construction of teacher powers. It is supposed to introduce more new excellent teacher powers, actively cultivate the original young teacher powers, and improve teachers' teaching ability and professional quality. In the daily teaching of the studio, the role of teachers is not only the imparter of knowledge and skills, but also the role of guidance, inspiration and help. It is necessary to establish an equal and harmonious relationship with students, to form a teaching and learning environment full of mutual development and humanistic concern, and form corresponding new teaching ideas and teaching methods facing the new teaching mode.

\section{Conclusion}

The reform and practice of the teaching mode in the practice studio of arts specialty in colleges and universities provide the greatest possibilities for the cultivation of compound higher vocational talents with comprehensive literacy, professional skills and innovative abilities. It is also a powerful means for the realization of the cultivation goal of professional talents. With the introduction of task-driven mode based on working process, the content of practical teaching becomes a practical task item suitable for social production, which enables students to understand the latest developments in the industry, realize zero-distance contact between the industry and employment, and improve students' employment competitiveness. At the same time, it can also cultivate students' innovative spirit and practice teamwork cooperation, communication and other abilities. Under the current situation of economic and social development, the establishment of studio-based mode conforms to the needs of the times, and it is an effective way to cultivate students' ability to adapt to market demand and solve the problem of employment and social adaptation. 


\section{References}

[1] Sherer R, Wan Y, Dong H, et al. Positive impact of integrating histology and physiology teaching at a medical school in China. Advances in Physiology Education, 2014, 38(4), pp. 330-338.

[2] Oberlander J. The Art of Repeal - Republicans' Health Care Reform Muddle. New England Journal of Medicine, 2017, 376(16), pp. 1497.

[3] Curry T. A theoretical basis for recommending the use of design methodologies as teaching strategies in the design studio. Design Studies, 2014, 35(6), pp. 632-646.

[4] Chiaradia A J F, Sieh L, Plimmer F. Values in urban design: A design studio teaching approach. Design Studies, 2017, 49, pp. 66-100.

[5] Dorta T, Kinayoglu G, Boudhraâ S. A new representational ecosystem for design teaching in the studio. Design Studies, 2016, 47, pp. 164-186.

[6] Zanin M K B. Creating \& Teaching with Simple Animation: Making Biology Instruction Come Alive. American Biology Teacher, 2015, 77(6), pp. 463-466. 